\title{
Simultaneous Administration of Aqueous Extract of Rosmarinus officinal with Nicotine Resulted in Prevention of Induced Hepatorenal Toxicity in Guinea Pigs
}

\author{
Azab Elsayed Azab*, Mohamed Omar Albasha \\ Department of Zoology, Faculty of Science, Zawia University, Alejelat, Libya \\ Email address: \\ azabelsaied@yahoo.com (A. E. Azab) \\ To cite this article: \\ Azab Elsayed Azab, Mohamed Omar Albasha. Simultaneous Administration of Aqueous Extract of Rosmarinus officinal with Nicotine \\ Resulted in Prevention of Induced Hepatorenal Toxicity in Guinea Pigs. American Journal of Bioscience and Bioengineering. \\ Vol. 3, No. 5, 2015, pp. 80-86. doi: 10.11648/j.bio.20150305.20
}

\begin{abstract}
Rosemary extracts have a high scavenging capacity of different types of reactive oxygen and nitrogen species, mostly free radicals. The present work aimed to evaluate the effectiveness of aqueous extract of rosemary as a natural source of antioxidants to minimize the harmful effects of nicotine induced hepatorenal toxicity in Guinea pigs. In this study, twenty four adult male Guinea pigs were used for this study and divided into four groups. The first group was control group, the $2^{\text {nd }}$ was the rosemary group orally received rosemary $\left(220 \mathrm{mg} / \mathrm{kg}\right.$ body weight /day), the $3^{\text {rd }}$ was the experimental and received intraperitoneal injection of nicotine $(6 \mathrm{mg} / \mathrm{kg}$ body weight $/ \mathrm{day})$, the $4^{\text {th }}$ one co-administered intraperitoneal injection of nicotine $(6 \mathrm{mg} / \mathrm{kg}$ body weight /day) and rosemary (220 mg/kg body weight /day) orally by gavage for 30 days. Blood samples were obtained for assessment of serum alanine aminotransferase, aspartate aminotransferase, alkaline phosphatase and $\gamma$-glutamyltransferase activities, total proteins, albumin, and globulin concentrations, albumin concentration/globulin concentration (A/G) ratio, urea, uric acid, creatinine, sodium ion, and potassium ion concentrations. In nicotine treated animals, the serum alanine aminotransferase, aspartate aminotransferase, alkaline phosphatase and $\gamma$ - glutamyl transferase activities, urea, uric acid, creatinine, and potassium ion concentrations were significantly $(\mathrm{p}<0.05)$, increased as compared to the control group. On the other hand, serum total proteins, albumin, and sodium ion concentrations of nicotine treated Guinea pigs, were significantly $(\mathrm{p}<0.05)$, decreased compared with control animals. But, globulin concentrations and A/G ratio were non significantly changed. Co-administration of rosemary significantly improved all biochemical parameters. It can be concluded that, simultaneous administration of aqueous extract of rosemary with nicotine resulted in prevention of induced hepatorenal toxicity in Guinea pigs. It is recommended that the heavy smokers should be advised to take rosemary as antioxidant to prevent the hepatorenal toxicity. Further studies are necessary to elucidate exact mechanism of hepatorenal protection and potential usefulness of aqueous extract of rosemary as a protective agent against nicotine induced hepatorenal toxicity in clinical trials.
\end{abstract}

Keywords: Hepatoprotective, Renoprotective, Rosemary (Rosmarinus officinalis), Male Guinea Pig, Nicotine

\section{Introduction}

Cigarette smoking and of the use of other tobacco products became an important cause of increased mortality and morbidity in developed countries [1]. Nicotine is the principal alkaloid contained in tobacco and it is believed to be the primary reason for cigarette smoking in many people particularly as they derive satisfaction and pleasant sensation from inhaling nicotine [2]. It is a highly toxic organic compound containing nitrogen and alkaloid [3]. People who smoke and also who are exposed to cigarette smoke indirectly by breathing the air in the same environment are exposed to nicotine induced oxidative stress [4, 5], Oxidative stress would result in increased free radical injury in the tissue leading to extensive tissue damage with subsequent derangement of cell physiology [1]. As a consequence, these radicals interact with cell components such as lipids, proteins, DNA, RNA, carbohydrates and enzymes $[4,5]$. So that smoking has an effect on the various metabolic and biological processes in the body [1]. During smoking, nicotine is rapidly absorbed into the circulatory system where more than $80 \%$ is metabolized in the liver. Liver is an important organ that has many tasks, and is responsible for processing drugs and other toxins to remove them from the body. Nicotine from heavy smoking increases 
the risk of developing hepatocellular carcinoma, chronic liver diseases. In addition, nicotine increases the production of pro-inflammatory cytokins that would be involved in liver cell injury [6]. Also, nicotine is hepatotoxic [7 - 9], and nephrotoxic [10].

The body is engaged in a constant battle against damaging chemicals called free radicals or pro-oxidants to counter the harmful effects of free radicals, the body manufactures antioxidants to chemically neutralize them. However, the natural antioxidant system may not always be equal to the task. Sources of free radicals, such as cigarette smoke may overwhelm this defense mechanism [11]. The antioxidants are important species that possess the ability to protect the body from damage caused by free radicals induced oxidative stress [12]. Medicinal plants and their active principles have received great attention as potential antiperoxidative agent [13].

Rosemary (Rosmarinus officinalis) is a herb commonly used as spice and flavoring agents in food processing and is useful in treatment of many diseases [14, 15]. It is composed of dried leaves and flowers constitutes a particularly interesting source of biologically active phytochemicals as it contains a variety of phenolic compounds including carnosol, carnosic acid, rosmanol, 7-methyl-epirosemanol, isorosmanol, rosmadial and caffeic acid $[14,16]$. Rosemary extracts have a high scavenging capacity of different types of reactive oxygen and nitrogen species, mostly free radicals, is thought to be one of the main mechanisms of the antioxidant action exhibited by phenolic phytochemicals [17]. The antioxidant activity of rosemary extract can be attributed mainly to two components, carnosic acid and carnosol [18]. It is useful in prevention of hepatotoxicity [19, 20], and nephrotoxicity [21]. The evidence reporting the amelioration by aqueous extract of rosemary in nicotine induced hepatorenal toxicity in Guinea pigs are hardly found. So, the present work aimed to evaluate ameliorating effect by aqueous extract of rosemary in nicotine induced hepatorenal toxicity in Guinea pigs.

\section{Materials and Methods}

\subsection{Chemicals}

Nicotine hydrogen tartrate salt [1-methyl-2- (3-pyridyl) pyrrolidine-bitartrate salt] was purchased from Sigma-Aldrich (St. Louis, MO, USA). The drug was dissolved in physiological saline $(0.9 \%$ sodium chloride $)$ and injected subcutaneously daily with $6 \mathrm{mg}$, nicotine / $\mathrm{kg}$ body weigh for 30 days. Nicotine $6 \mathrm{mg} / \mathrm{kg}$ body weight was prepared by mixing $60 \mathrm{mg}$ of nicotine in $10 \mathrm{ml}$ normal saline. A total of 1 $\mathrm{ml} / \mathrm{Kg}$ body weight of the nicotine. The selection of the nicotine dose (6 $\mathrm{mg} / \mathrm{kg}$ body weight) in the present study was based on approximate the plasma levels reported in heavy smokers [22] and previous published studies [23, 24].

Fresh rosemary (Rosmarinus Officinalis L) was collected from Surman city, West Libya between the month of May and June 2015 . The plant was dried under shade at $25^{\circ} \mathrm{C}$ and the dried leaves of plant were grounded with a blender. Aqueous rosemary extract was prepared according to the method of Amin and Hamza [25]. Briefly, twenty gram of dried plants was slowly boiled in $100 \mathrm{ml}$ of distilled water and heated for 30 minutes. The extracts were then filtered and directly administered orally by gavage to the animals at a volume of $5 \mathrm{ml} / \mathrm{kg}$ body weight $(220 \mathrm{mg} / \mathrm{kg}$ body weight). The selection of the rosemary dose (220 mg/ kg body weight) was based on previous published studies $[15,21,26]$.

\subsection{Animals}

Twenty four adult male Guinea pigs (Cavia porcellus) weighting 450-600 gm were used for this study. The animals were obtained from animal house unit in the faculty of veterinary medicine, Tripoli University, Libya. The animals were housed in a room under standard conditions of ventilation, temperature $\left(25 \pm 2^{\circ} \mathrm{C}\right)$, humidity $(60-70 \%)$ and light/dark condition (12/12). The animals were provided with tape water ad libitum and fed with the standard commercial chow. The animal procedures were performed in accordance with Guide Lines for Ethical Conduct in the Care and Use of Animals.

\subsection{Experimental Design}

After one week of acclimation, the animals were randomized and divided into four groups (6 Guinea pigs for each) as follow:

Group I (Control group): The animals received intraperitoneal injection of saline $(0.5 \mathrm{ml} /$ day $)$ for 30 days.

Group II (Rosemary group): The animals received rosemary ( $220 \mathrm{mg} / \mathrm{kg}$ body weight /day) orally by gavage for 30 days.

Group III (Nicotine treated group): The animals received intraperitoneal injection of nicotine only $(6 \mathrm{mg} / \mathrm{kg}$ body weight /day) for 30 days.

Group IV (Nicotine/rosemary co-administered): The animals received intraperitoneal injection of nicotine $(6 \mathrm{mg} / \mathrm{kg}$ body weight /day) and rosemary ( $220 \mathrm{mg} / \mathrm{kg}$ body weight /day) orally by gavage for 30 days.

At the end of the experimentation and 24 hours after the last dose, all animals were sacrificed under light ether anesthesia, then rapidly dissected and subjected to the following examinations:

\subsection{Biochemical Analysis}

Blood samples were drawn by cardiac puncture. The sample was collected in clean dry tube and centrifuged at 3000 rpm for 15 minutes then, serum was separated and kept in a deep freezer at $-20^{\circ} \mathrm{C}$ until biochemical measurements were carried out. The activities of Alanine aminotransferase (ALT), aspartate aminotransferase (AST) were determined in serum according to the methods described by Reitman and Frankel [27]. Serum alkaline phosphatase (ALP) activity was determined according to Kind et al. [28]. Serum $\gamma$-GT activity was determined according to the method of Szas [29].

Serum total proteins concentration was determined 
according to Biuret method explained by Weichselbaum [30]. Serum albumin concentration was determined according the method of Doumas et al. [31]. Serum globulin concentration was determined according to the formula: Globulin $=$ total protein-albumin.

The ratio of serum albumin concentration /globulin concentration $(\mathrm{A} / \mathrm{G})$ was determined as albumin / globulin level. Serum urea measurement was based upon the cleavage of urea with urease [32]. Serum uric acid was determined [33]. Serum creatinine was measured without protein precipitation [34]. Sodium concentration in serum was determined by colorimetric method according to Trinder [35], and Maruna [36]. Potassium concentration in serum was determined by turbidimetric tetraphenylborate method according to Hoeflmayr [37]. Using Chiron diagnostics kits.

\subsection{Statistical Analysis}

The values were presented as means \pm SD of different groups. Differences between the mean values were estimated using one way ANOVA. The results were considered statistically significant when $\mathrm{p}<0.05$.

\section{Results}

Biochemical parameters in serum of the different groups are shown in Table 1. Guinea pigs that received intraperitoneal injection of nicotine only $(6 \mathrm{mg} / \mathrm{kg}$ body weight /day) for 30 days had significantly $(p<0.05)$, increased the serum alanine aminotransferase, aspartate aminotransferase, alkaline phosphatase and $\gamma$ - glutamyl - transferase activities, urea, uric acid, creatinine, and potassium ion concentrations as compared to the control Guinea pigs. Co-administration of nicotine with rosemary were significantly $(p<0.05)$ prevented the changes recorded in serum liver function serum enzymes activities, and serum kidney function parameters as compared with control group. On the other hand, serum total proteins, albumin, and sodium ion concentrations of nicotine treated Guinea pigs were significantly $(\mathrm{p}<0.05)$ decreased as compared to the control Guinea pigs, but, globulin concentrations and $\mathrm{A} / \mathrm{G}$ ratio were non significantly changed as compared to the control Guinea pigs. Co-administration of nicotine with rosemary were significantly $(\mathrm{p}<0.05)$ prevented the changes recorded in serum total proteins, albumin, and sodium ion concentrations as compared with control group.

Table 1. Effect administration of Guinea pigs to aqueous extract of rosemary and/ or nicotine on serum biochemical parameters.

\begin{tabular}{|c|c|c|c|c|}
\hline \multirow{3}{*}{ Parameters } & \multicolumn{4}{|l|}{ Groups } \\
\hline & Control & Rosemary & Nicotine & Nicotine + Rosemary \\
\hline & Mean + SD & Mean + SD & Mean + SD & Mean + SD \\
\hline Alanine aminotransferase (U/L) & $57.50 \pm 2.43$ & $59.00 \pm 2.38$ & $75.33 \pm 3.25^{\mathrm{a}}$ & $66.14 \pm 2.11^{\mathrm{b}}$ \\
\hline Aspartate aminotransferase $(U / L)$ & $83.83 \pm 2.91$ & $85.17 \pm 2.85$ & $110.83 \pm 6.67^{\mathrm{a}}$ & $98.7 \pm 3.97^{\mathrm{b}}$ \\
\hline Alkaline phosphatase (U/L) & $41.5 \pm 1.50$ & $44.17 \pm 2.97$ & $55.17 \pm 1.34^{\mathrm{a}}$ & $48.8 \pm 2.41^{\mathrm{b}}$ \\
\hline$V$-glutamyl transferase activities $(U / L)$ & $19.67 \pm 1.11$ & $20.83 \pm 1.41$ & $28.55 \pm 0.96^{\mathrm{a}}$ & $23.10 \pm 1.20^{\mathrm{b}}$ \\
\hline Albumin concentration $(\mathrm{g} / \mathrm{dl})$ & $3.70 \pm 0.13$ & $3.53 \pm 0.11$ & $3.13 \pm 0.06^{\mathrm{a}}$ & $3.56 \pm 0.09^{\mathrm{b}}$ \\
\hline Globulin concentration ( $g / d l)$ & $3.05 \pm 0.21$ & $3.42 \pm 0.28$ & $2.77 \pm 0.20$ & $2.99 \pm 0.06$ \\
\hline$A / G$ ratio & $1.22 \pm 0.13$ & $1.04 \pm 0.11$ & $1.13 \pm 0.08$ & $1.19 \pm 0.05$ \\
\hline Urea concentration ( $\mathrm{mg} / \mathrm{dl})$ & $21.50 \pm 1.71$ & $22.33 \pm 1.97$ & $30.17 \pm 3.24^{\mathrm{a}}$ & $26.00 \pm 1.53^{\mathrm{b}}$ \\
\hline Creatinine concentration $(\mathrm{mg} / \mathrm{dl})$ & $0.50 \pm 0.04$ & $0.51 \pm 0.02$ & $1.02 \pm 0.12^{\mathrm{a}}$ & $0.78 \pm 0.06^{\mathrm{b}}$ \\
\hline Uric acid concentration $(\mathrm{mg} / \mathrm{dl})$ & $1.35 \pm 0.06$ & $1.33 \pm 0.06$ & $1.66 \pm 0.09^{\mathrm{a}}$ & $1.48 \pm 0.07^{\mathrm{b}}$ \\
\hline Sodium ion concentration $(\mathrm{mmol} / \mathrm{L})$ & $136.5 \pm 2.06$ & $137.2 \pm 1.34$ & $132.0 \pm 1.91^{\mathrm{a}}$ & $135.6 \pm 1.25^{\mathrm{b}}$ \\
\hline Potassium ion concentration $(\mathrm{mmol} / \mathrm{L})$ & $4.65 \pm 0.19$ & $4.48 \pm 0.13$ & $5.68 \pm 0.35^{\mathrm{a}}$ & $5.01 \pm 0.27^{\mathrm{b}}$ \\
\hline
\end{tabular}

a: Significant differences as compared with control group $(\mathrm{P}<0.05)$. b: Significant differences as compared with nicotine treated group $(\mathrm{P}<0.05)$.

All data are mean of 6 individuals.

\section{Discussion}

Oxidative stress results from an imbalance between the cellular production of reactive oxygen species and the antioxidant mechanisms that remove them [36]. The relationship between the amount of products of oxidative metabolism and natural scavengers of free radicals determines the outcome of tissue damage. Overproduction of reactive oxygen metabolites and a reduction in antioxidant mechanisms have been reported due to acute or chronic smoke exposure [39]. However; nicotine which is a major toxic component of cigarette smoke has been shown to produce diffuse damage to endothelium and plays a major role in the development of numerous human disease or disorders [40].

The present study demonstrated that nicotine treatment caused significant increases in the serum ALT, AST, ALP and V-GT activities and decreases in the serum total proteins, albumin and indicating impaired liver function. Similar results were also reported by Jang et al., [41] and Sharif et al., [42]. Fahim et al., [43] reported rise in both hepatic ALT and AST levels following i.p nicotine injection $(1 \mathrm{mg} / \mathrm{Kg})$ for 3 weeks in mice. Another study observed over expression of ALP level and other genes involved in osteoblast maturation and differentiation in osteoblasts in response to subtoxic nicotine administration in humans [44]. Also, Mahmoud and Amer [45] found that significant elevations in the activities of ALT, AST, and alkaline phosphatase in liver homogenate of nicotine treated rats compared with control group. These results may be attributed to the state of hypoxia of the parenchyma for contracting fibrous tissue and the increased permeability of 
hepatic cell membrane due to nicotine treatment which release ALT enzyme into the circulation. The increased level of ALT is marked as liver parenchymal cell destruction induced by nicotine treatment. The elevation in serum ALT activity observed in the present study may reflect hepatotoxic potency of subchronic exposure of nicotine on liver. This effect could be an essential process for the liver to restore the balance of different free amino acids that might have been disturbed throughout recovering mechanisms. It has been established that the liver is the sole source for the synthesis of albumin, fibrinogen and most of Alpha and $\beta$ globulins, while the immunoglobulin are formed in the lymphoid tissues by the plasma cell [46]. Accordingly, the liver affected by nicotine may suffer from dysfunctions and this may modify the synthesis and metabolism of proteins. This might explain the significant decrease observed in the total serum proteins in Guinea pigs treated with nicotine. The results are also in accordance with the work of Sershen et al., [47] who found that, injection of nicotine produced inhibition of protein synthesis, due to exposure to cigarette smoke.

The elevated serum levels of urea and creatinine indicate reduced ability of the kidney to eliminate the toxic metabolic substances [48]. Nicotine and its metabolites are eliminated from kidney, these organs are adversely influenced by nicotine. Membrane lipids are vital for the maintenance and integrity of cell function, the breakdown of membrane phospholipids and lipid peroxidation due to the generation of free radicals are expected to change membrane structure, fluidity, transport and antigenic properties, all of which play an important role in the pathogenesis of organ disorders [49]. Indeed, increasing evidence suggests that chronic cigarette smoking adversely influences the prognosis of nephropathies $[49,50]$.

In the present study, the serum urea, creatinine and uric acids were significantly increased in Guinea pigs treated with nicotine compared with control animals suggesting an impairment of kidney function. The observed alterations in renal function parameters are in line with the reports by these findings are agreement with the results of other studies $(10 \&$ 51-54]. This is agree with the findings of Ahmed et al., [55] who found that the levels of creatinine and urea were significantly higher in smoker group when compared with the control group. There is evidence that an increase in renal retention of uric acid can occur in cases of acute or chronic renal disease/ failure [56]. Several mechanisms may be operative in inducing renal vasoconstriction and vascular damage. Nicotine increases plasma levels of vasoconstrictors including catecholamines, arginine, vasopressin and endothelin-1 [57]. Cigarette smoke damages endothelial cells, and nicotine induces smooth muscle cell proliferation [58]. Other study attributed the renovascular resistance to activation of the sympathetic nervous system [59]. These effects could be attributed to changes in the threshold of tubular re-absorption, renal blood flow and glomerular filtration rate [60].

The present study shows that, treatment of Guinea pigs with nicotine were caused a significant decrease in serum sodium ions and increase in serum potassium ions concentrations compared with control group. This is in agreement with Hozayen et al., [61] who found that, the administration of aspartame showed a highly significant decrease in serum sodium concentration and increasing in potassium concentration when compared to normal rats, this action may be due to inhibition of $\mathrm{Na}+, \mathrm{K}+$-ATPase activity. The $\mathrm{Na}+$, $\mathrm{K}+$ - AT Pase is a complex membrane protein that utilizes ATP to transport three $\mathrm{Na}+$ ions out of cells and two $\mathrm{K}+$ ions in against their concentration gradients [62].

Rosemary is used in folk medicine, as an antispasmodic in renal colic and dysmenorrhea, in relieving respiratory disorders, and to stimulate growth of hair [63]. The aqueous extract of rosemary used as a drug with strong antioxidant properties for eliminating the generated free radicals, reinforce the antioxidant system and prevent oxidative stress [64].

The present study, revealed that co-administration of nicotine and aqueous extract of rosemary significantly decreased the elevations in the serum ALT, AST, ALP, and $\mathrm{V}$-GT activities and increased the levels of serum total proteins and albumin a compared with nicotine treated group. This results are run in parallel with the results of Abd El Kader et al., [65] who found that, a significant improving effect of pre-treatment with rosemary on the altered activities of serum ALT, AST, GGT and ALP induced by $\mathrm{Pb}$-acetate intoxication. The observed decrease in these serum marker enzymes shows that rosemary preserves the structural integrity of liver against lead-induced damage. Mannaa et al., [66] reported that, the hepatotoxic effects of $\mathrm{AlCl}_{3}$, as indicated by significant augmentations of serum ALT and AST levels can be modified by rosemary supplementation in combination with $\mathrm{AlCl}_{3}$. These protective effects of rosemary may be attributed to its antioxidant and free radical scavenging activities due to its higher contents of polyphenolic compounds (66, 67). Phytochemical studies have shown that rosemary contains essential oils, terpenoids, flavonoids and alkaloids. Some of its constituents such as rosmarinic acid have been reported as powerful antioxidant protecting against free radicals damage and to reduce hepatotoxicity [68]. It is generally assumed that these antioxidant molecules from rosemary may act as free radical scavengers but additionally might play a role by regulating the activity and/or expression of certain enzymatic systems implicated in relevant physiological processes like apoptosis, or xenobiotic-metabolizing enzymes in liver [69].

In the present study, co-administration of rosemary to animals treated with nicotine were significantly decreased the serum urea, creatinine and uric acid compared with nicotine treated group. This is in agreement with Azab et al., [21] who found that co-treatment of gentamicin and rosemary aqueous extract significantly decreased the serum urea, creatinine and uric acid compared with gentamicin treated group. The treatment of aspartame administered rats with rosemary extract induced a highly significant decrease in the levels of urea and creatinine when compared with corresponding groups [61]. Sahu et al., [70] found that carnosic acid treatment $(100 \mathrm{mg} / \mathrm{kg} /$ day oral $)$ before cisplatin 
administration, efficiently reduced acute nephrotoxicity by preventing the increase in blood urea nitrogen and serum creatinine level. Pre-administration of rosemary alleviates the harmful effects induced by lead acetate by improvement the kidney functions [63]. Mannaa et al., [66] reported that, renal dysfunctions of $\mathrm{AlCl}_{3}$, as indicated by significant augmentations of serum urea and creatinine levels, can be modified by rosemary supplementation in combination with $\mathrm{AlCl}_{3}$. The rosemary aqueous extract alleviates the toxicity induced by lead on the kidney through stimulation of endogenous antioxidant defense system [65]. Also, the rosemary aqueous extract alleviates the nephrotoxicity induced by $\mathrm{CCL}_{4}$ in albino rats [15]. It is generally assumed that these antioxidant molecules from rosemary may act as free radical scavengers but additionally might play a role by regulating the activity and/or expression of certain enzymatic systems implicated in relevant physiological processes like apoptosis, tumour promotion and intracellular signal transduction [71]. The protective effect of rosemary can be explained that rosemary extract has a high scavenging capacity of different types of reactive oxygen and nitrogen species, mostly free radicals, as thought to be one of the main mechanisms of the antioxidant action exhibited by phenolic phytochemicals [17]. Also, Rosemary extracts are able to donate electrons to reactive radicals, converting them to more stable and on reactive species, therefore preventing them from reaching biomolecules, such as lipoproteins, polyunsaturated fatty acids, DNA, amino acids, proteins and sugars, in susceptible biological systems [15, 26, $61 \& 72]$.

This study shows that, co-administration of nicotine and aqueous extract of rosemary to Guinea pigs were caused a significant increase of sodium ions and decrease potassium ions concentrations compared with nicotine treated group. This is in agreement with Hozayen et al., [61] who reported that, the treatment of aspartame administered rats with rosemary extract induced a significant increase in serum sodium and decrease in potassium levels in comparison with corresponding groups. This may be due to the antioxidant properties of extracts of rosemary leaves. It is generally assumed that these antioxidant molecules from rosemary may act as free radical scavengers but additionally might play a role by regulating the activity and/or expression of certain enzymatic systems implicated in relevant physiological processes like apoptosis, tumour promotion and intracellular signal transduction [71].

The biological activities of rosemary aqueous extracts are mainly attributed to their high concentration of phenolic constituents namely carnosic and rosmarinic acids that are recognized as natural antioxidants [73, 74]. Many studies reported that the preventive effects of rosemary and its extracts are attributed to its antioxidant activity [75].

\section{Conclusion}

The present study concluded that, simultaneous administration of aqueous extract of rosemary with nicotine resulted in prevention of induced hepatorenal toxicity in
Guinea pigs. It is recommended that the heavy smokers should be advised to take rosemary as antioxidant to prevent the hepatorenal toxicity. Further studies are necessary to elucidate exact mechanism of hepatorenal protection and potential usefulness of aqueous extract of rosemary as a protective agent against nicotine induced hepatorenal toxicity in clinical trials.

\section{References}

[1] Abdel-Aziz HO: Morphological evaluation on the protective effect of curcumin on nicotine induced histological changes of the adrenal cortex in mice. Egypt J Histol 2010; 33(3): 552 559 .

[2] Benowitz NL, Florence MD, Kuyt MD and Jacob P: Circadian Bloodnicotine concentration, during cigarette smoking. Clin. Pharmacol. Ther 1982; 32(6): 758.

[3] Jana K, Samanta PK and De DK: Nicotine diminishes testicular gametogenesis, steroidogenesis, and steroidogenic acute regulatory protein expression in adult albino rats: possible influence on pituitary gonadotropins and alteration of testicular antioxidant status. Toxicol. Sci., 2010; 116(2): 647- 659.

[4] Suleyman H, Gumustekin K, Taysi S, Keles S, Oztasan N, Aktas O, Altinkaynak K, Timur H, Akcay F, Akar S, Dane S and Gul M: Beneficial effects of Hippophae rhamnoides L. on nicotine induced oxidative stress in rat blood compared with vitamin E. Biol Pharm Bull 2002; 25(9): 1133-1136.

[5] Ekinci D, Senturk M, Beydmir S, Kufrevioglu OI and Supuran CT: An alternative purification method for human serum paraoxnase and its interactions with sulfonamides. Chem Biol Drug Design 2010; 76(6): 552- 558.

[6] El-Zayadi AR: Heavy smoking and liver. World J Gastroenterol 2006; 12(38): 6098-6101.

[7] Sharif S, Farasat T, Fatima N, Farooq A, and Naz S: Nicotine effect on hematology, lipid and liver profile. Advanc Animal Veter Sci 2014; 2 (4): 222 - 225.

[8] Mercan S and Eren B: Protective role of melatonin supplementation against nicotine induced liver damage in mouse. Toxicol Ind Health 2013; 29(10): 888-896.

[9] Metwally FG, Karam SH, Elshazli EM, Abdel Ghaffar A, Mahmoud AM and Aziz MA: Protective effect of curcumin on nicotine-induced toxicity of liver and kidney in rats. Review Res 2015; 4 (5): 3-14.

[10] Abu-El-Zahab HSH, El-Naggar MH, El-Khat ZA, Bashandy SAE, El-Saify, A, and Moharran, NZ: Effect of nicotine administration of the activity of some serum and liver enzymes of male albino rats. J Egypt Ger Soc Zool 1994; 15 (A): 345-354.

[11] EBSCO, CAM (on line): Review board: Conditions: Atherosclerosis and heart disease prevention, 2007; pp. 4.

[12] Robinson E, Maxwell S and Thorpe G: An investigation of antioxidant activity of black tea, using enhanced chemiluminescence's free radial. Res 1997; 26(3): 291-300.

[13] Lee BM, and Park KK: Beneficial and adverse effects of chemoprotective agents. Mutat Res 2003: 265-270. 
[14] Ho C, Ferrara T, Chen Q, Rosen R and Huang M: Phytochemicals in teas and rosemary and their cancer preventive properties in: food phytochemicals for cancer prevention. Amer Chem Soc Washington 1994:2-19.

[15] Sakr SA and Lamfon HA: Protective effect of rosemary (Rosmarinus officinalis) leaves extracts on carbon tetrachloride-induced nephrotoxicity in albino rats. Life Sci J 2012; 9(1): 779-785.

[16] Aruoma O, Halliwell B, Aeschbach R and Loligers J: antioxidant and pro-oxidant properties of active rosemary constituents: carnosol and carnosic acid. Xenobiotica 1992; 22: 257-268.

[17] Moreno S, Scheyer T, Romano CS and Vojnov AA: Antioxidant and antimicrobial activities of rosemary extract linked to their polyphenol composition. Free Rad Res 2006; 40(2): 223-231.

[18] Kadri A, Zarai Z, Ben Chobba I, Bekir A, Gharsallah N, Damak $\mathrm{M}$ and Gdoura R: Chemical constituents and antioxidant properties of Rosmarinus officinalis L. essential oil cultivated from South-Western Tunisia. J Med Plants Res 2011; 5: 5999 . 6004 .

[19] Yu MH, Choi JH, Chae IG, Im HG, Yang SA, More K, Lee IS and Lee J: Suppression of LPS-induced inflammatory activities by Rosmarinus officinalis L. Food Chem 2013; 136: 1047-1054.

[20] Raskovic A, Milanovic I, Pavlovic N, Cebovic T, Vukmirovic S and Mikov M: Antioxidant activity of rosemary (Rosmarinus officinalis L.) essential oil and its hepatoprotective potential. BMC Compl Alter Med 2014; 14(225): 1 - 9.

[21] Azab AE, Fetouh FA and Albasha MO: Nephro-protective effects of curcumin, rosemary and propolis against gentamicin induced toxicity in Guinea pigs: Morphological and biochemical study. Amer J Clin Exper Med 2014; 2(2): 28-35.

[22] Matta SG, Balfour DJ, Benowitz NL, Boyd RT, Buccafusco JJ, Caggiula AR, Craig CR, Collins AC, Damaj MI, Donny EC, Gardiner PS, Grady SR, Heberlein U, Leonard SS, Levin ED, Lukas RJ, Markou A, Marks MJ, McCallum SE, Parameswaran N, Perkins KA, Picciotto MR, Quik M, Rose JE, Rothenfluh A, Schafer WR, Stolerman IP, Tyndale RF, Wehner JM and Zirger JM: Guidelines on nicotine dose selection for in vivo research. Psychopharmacol (Berl), 2007; 190: 269-319.

[23] Abreu-Villaca Y, Seidler FJ, Tate CA and Slotkin TA: Nicotine is a neurotoxin in the adolescent brain: Critical periods, patterns of exposure, regional selectivity and dose thresholds for macromolecular alterations. Brain Res 2003; 979: 114-128.

[24] Jain A and Flora SJS: Dose related effects of nicotine on oxidative injury in young, adult and old rats. J Environ Biol 2012; 33: 233-238.

[25] Amin A, and Hamza AA: Hepatoprotective effects of hibiscus, rosemarinus and salvia on azathioprine-induced toxicity in rats. Life Sci 2005; 77: 266-278.

[26] Dorman HJ, Peltoketo A, Hiltunen R and Tikkanen MJ: Characterization of the antioxidants properties of deodourised aqueous extracts from selected Lamiaceae herbs. Food Chem 2003; 83: 255-262.

[27] Reitman S and Frankel A: Colorimetric method for determination of serum glutamate oxaloaectate and glutamic pyruvate transaminase. Amer J Clin Pathol 1957; 28: 56-58.
[28] Kind PRN, King EJ, Varley H, Gowenlock AH and Bell M: Method of practical clinical biochemistry. Heinman, London, 1980, pp. 899-900.

[29] Szas G: Reaction rate method for gamma glutamyl transferase activity in serum. Clin Chem 1976; 22: 2031-2055.

[30] Weichselbaum TE: Determination of total protein. Amer Clin Path 1946; 16: 40 -48.

[31] Doumas BT, Watson WA and Homer CB: Albumin standard and measurement of the albumin with bromocresol green. Clin Chem Acta 1971; 31: 87-96.

[32] Fawcett JK and Scott JE: A rapid and precise method for the determination of urea. J Clin Path 1960; 13: 156 -159.

[33] Fossatti P, Prencipe L and Berti G; Use of 3, 5-dichloro 2-hydroxybenzenesulfonic acid/4-amino-phenazone chromogenic system indirect enzymic assay of uric acid in serum and urine. Clin Chem 1980; 26: 227- 231.

[34] Bartels H, Bohmer $M$ and Heierli C: Serum creatinine determination without protein precipitation. Clin Chim Acta 1972; 37: 193-197.

[35] Trinder P: A rapid method for the determination of sodium in serum. Analyst 1951; 76: 596-599.

[36] Maruna RFL: Clin Chim Acta 1958; 2: 581.

[37] Hoeflmayr J : Praxis and Helferin 1979.p.8.

[38] Posadas SJ, Caz V, Largo C, De la Gándara B, Matallanas B, Reglero G and De Miguel E: Protective effect of supercritical fluid Rosemary extract, Rosmarinus officinalis, on antioxidants of major organs of aged rats. Exp. Gerontol 2009; 44: 383-389.

[39] Van der Vaart, H, Postma, DS, Timens, W and Ten Hacken, $\mathrm{NH}$ : Acute effects of cigarette smoke on inflammation and oxidative stress: a review. Thorax 2004; 59: 713-721.

[40] Mayhan WG and Sharpe GM: Chronic exposure to nicotine alters endothelium-dependent arteriolar dilatation: Effect of superoxide dismutase. J Appl Physiol 1999; 86: 1126-1134.

[41] Jang ES, Jeong SH, Hwang SH, Kim HY, Ahn SY, Lee J, Lee SH, Park YS, Hwang JH, Kim JW, Kim N and Lee DH: Effects of coffee, smoking, and alcohol on liver function tests: a comprehensive cross-sectional study. BMC Gastroenterol 2012; $12: 145$.

[42] Sharif S, Farasat T, Fatima N, Farooq A and Naz S: Effect of nicotine on hematology, lipid profile and liver enzymes in adult male mice (Mus musculus). Advan Anim Veter Sci 2014; 2 (4): $222-225$

[43] Fahim MA, Nemmar A, Al-Salam S, Dhanasekaran S, Shafiullah M, Yasin J and Hassan MY: Thromboembolic injury and systemic toxicity induced by nicotine in mice. Gen Physiol Biophys 2014; 33(3): 345-355.

[44] Marinucci L, Bodo M, Balloni S, Locci $\mathrm{P}$ and Baroni $\mathrm{T}$ : Sub-toxic nicotine concentrations affect extracellular matrix and growth factor signaling gene expressions in human osteoblasts. J Cell Physiol 2014; 229(12): 2038-2048.

[45] Mahmoud GS and Amer AS: Protective effects of vitamin C against nicotine-induced oxidative damage of rat liver and kidney. IOSR-JESTFT 2014; 8(12): 50-63. 

with Nicotine Resulted in Prevention of Induced Hepatorenal Toxicity in Guinea Pigs

[46] Mohamed TA, El-Aaser ABA and Abo-El-Alla WA: Nicotine effects on total body weight, survival rate and serum protein content in mice. J Egypt Ger Soc Zool 1992; 7 (A): 209-217.

[47] Sershen H, Reith ME, Banay-Schwartz M and Lajtha A: Effects of prenatal administration of nicotine on amino acid pools, protein metabolism, and nicotine binding in the brain. Neurochem Res 1982; 7: 1515-1522.

[48] Hummadi LA: Histopathological and ultrastructural changes in renal corpuscle of female rats topical application by P-phenylene diamine. Inter J Zool Res 2012; 8: 106-120.

[49] Sener G, Toklu HZ and Cetinel S: $\beta$-Glucan protects against chronic nicotine-induced oxidative damage in rat kidney and bladder. Environ Toxicol Pharmacol 2007; 23: 25-32.

[50] Zeegers MP, Goldbohm RA and van den Brandt PA: Aprospective study on active and environmental tobacco smoking and bladder cancer risk. Cancer Causes Contr 2002; 13: $83-90$.

[51] El Sayed SM, Mahmoud HS and Nabo MMH: Medical and scientific bases of wet cupping therapy (Alhijamah): in light of modern medicine and prophetic medicine. Alter Integ Med 2013: 2-5.

[52] Noborisaka Y, Ishizaki M, Nakata M, Yamada Y, Honda R, Yokoyama H, Miyao M and Tabata M: Cigarette smoking, proteinuria, and renal function in middle-aged Japanese men from an occupational population. Environ Health Prev Med 2012; 17: 147-156.

[53] Pramod KA, Surender K, Chander MP, Kim V and Krishan LK: Smokeless tobacco impairs the antioxidant defense in liver, lung and kidney of rats. Toxicol Sci 2006; 89 (2): 547-553.

[54] Okonkwo LO, Dada FL, Ugbor CI, Nwadike IG, Eze NO, and Ozougwu CP: Tobacco induced renal function alterations in wistar rats: An 8 weeks study. IJHPR 2013; 2(3): 29 - 35.

[55] Ahmed MME, Jawad ASA, Osman HM and Shayoub ME: The effect of smoking cigarette on kidney functions among sundaes peoples. Inter J Develop Res 2015; 5(5): 4473-4475.

[56] Newman DJ and Price CP: Renal function and nitrogen metabolites. In: Tietz textbook of clinical chemistry. 3rd edition. Burtis, C.A and Ashwood, E.R. (editors). W. B. Saunders, Philadelphia. 1998: 1204-1270.

[57] Gambaro G, Verlato F, Budakovic A et al.: Renal impairment in chronic cigarette smokers. J Am Soc Nephrol 1998; 9: 562-567.

[58] Pittilo RM, Bull HA and Gulati S et al.: Nicotine and cigarette smoking: Effects on the ultrastructure of aortic endothelium". Int J Exp Patho. 1990; 71: 573-586.

[59] Black HR, Zeevi GR, Silten RM and Smith GJW: Effect of heavy cigarette smoking on renal and myocardial arterioles. Nephron 1983; 34: 173-179.

[60] Zurovsky Y and Haber C: Antioxidants attenuate endotoxin generation induced acute renal failure in rats. Scand J Urol Nephrol 1995; 29: 147-154.

[61] Hozayen WG, Soliman HAE and Desouky EM: Potential protective effects of rosemary extract, against aspartame toxicity in male rats. J Inter Acad Res Multidisc 2014; 2(6):111-125.

[62] Lingrel JB: The physiological sgnificance of the cardiotonic steroid/ouabain binding site of the Na, K-ATPase. Annu Rev Physiol 2010; 72: 395- 412.
[63] Nusier MK, Bataineh HN and Daradkah HM: Adverse effects of rosemary (Rosmarinus officinalis L.) on reproductive function in adult male rats. Exper Biol Med 2007; 232(6): 809 813.

[64] Zohrabi M, Ashtiyani SC, Hajihashemi S, Hassanpoor A and Hosseini N: The study of $24 \mathrm{H}$ post treatment effects of the aqueous extract of Rosmarinus officinalis after renal ischemia/reperfusion in rat. J Physiol Pathophysiol 2012; 3(2): 12-19.

[65] Abd El Kader MA, El-Sammad NM and Taha H: The protective role of rosemary (Rosmarinus officinalis) in lead acetate induced toxicity in rats. J Appl Sci Res 2012; 8(6): 3071-3082.

[66] Mannaa FA, Abdalla MS., Abdel-Wahhab KG and EL-Kassaby MI: Effect of some nutraceutical agents on aluminum-induced functional neurotoxicity in senile rats: I. Effect of rosemary aqueous extract and docosahexaenoic acid. J Appl Sci Res 2013; 9(3): 2322-2334.

[67] Sotelo-Felix JI, Martínez-Fong D, Muriel P, Santillá RL, Castillo D and Yahuaca P: Evaluation of the effectiveness of Rosmarinus officinalis (Lamiaceae) in the alleviation of carbon tetrachloride-induced acute hepatotoxicity in the rat. J Ethnopharmacol 2002; 81: 145-154.

[68] Martínez AL, Gonzalez-Trujano ME, Chavez M and Pellicer F: Antinociceptive effectiveness of triterpenes from rosemary in visceral nociception. J Ethnopharmacol 2012; 142: 28-34.

[69] Offord EA, Gautier JC, Avanti O, Scaletta C, Runge F, Krämer $\mathrm{K}$ and Applegate LA: Photoprotective potential of lycopene, beta-carotene, vitamin $\mathrm{E}$, vitamin $\mathrm{C}$ and carnosic acid in UVA-irradiated human skin fibroblasts. Free Rad Biol Med 2002; 32: 1293-1303.

[70] Sahu BD, Rentam KKR, Putcha UK, Kuncha M, Vegi GMN and Sistia R: Carnosic acid attenuates renal injury in an experimental model of rat cisplatin-induced nephro- toxicity. Food Chem Toxicol 2011; 49: 3090 - 3097.

[71] Perez-Fons L, Aranda FJ, Guillen J, Villalain J and Micol V: Rosemary (Rosmarinus officinalis) diterpenes affect lipid polymorphism and fluidity in phospholipids membranes. Arch Biochem Biophys 2006; 453: 224-236.

[72] Bozin B, Mimica-Dukic N and Samojli K: Antimicrobial and antioxidant properties of rosemary and age. Essential oils. J Agric Food Chem 2007; 57: 879-7885.

[73] Mulinacci N, Innocenti M, Bellumori M, Giaccherini C, Martini V and Michelozzi M: Storage method, drying processes and extraction procedures strongly affect the phenolic fraction of rosemary leaves: An HPLC/DAD/MS study. Talanta 2011; 85: 167 - 176.

[74] Erkan N, Ayranci G and Ayranci E: Antioxidant activities of rosemary (Rosmarinus officinalis L.) extract, blackseed (Nigella sativa L.) essential oil, carnosic acid, rosmarinic acid and sesamol. Food Chem 2008; 110: 76-82.

[75] Marzieh Z, Saeed C, Saeed H and Akbar H. The study of $24 \mathrm{~h}$ post treatment effects of the aqueous extract of Rosmarinus officinalis after renal ischemia/reperfusion in rat. J Phys 2012; 2: 12-19. 